\title{
Supply Chain Flexibility: Managerial Implications
}

\author{
Dilek Önkal and Emel Aktas \\ Brunel Business School, Brunel University, \\ United Kingdom
}

\section{Introduction}

Today's companies are forced into functioning in a challenging business world with extensive uncertainties. Frontrunners turn out to be those companies that are able to foresee the market swings and react swiftly with minimal adjustment costs and effective response strategies. Hence, developing flexibility in adapting to sudden changes in global markets, resource availabilities, and outbreaks of financial and political crises becomes an integral part of effective management strategy. Supply chain management presents an especially important domain where such flexibility is critical to achieving a consistently successful performance.

Earlier research on flexibility in supply chains has focused primarily on manufacturing (e.g., Barad \& Nof, 1997; De Toni \& Tonchia, 1998; Gupta \& Goyal, 1989; Kaighobadi \& Venkatesh, 1994; Koste \& Malhotra, 1999; Mascarenhas, 1981; Parker \& Wirth, 1999; Sethi \& Sethi, 1990). In contrast, recent studies have tended to examine a proliferation of different dimensions like volume, launch, and target market flexibilities (Vickery, Calantone \& Drőge, 1999); logistics flexibility potentially including flexibilities in postponement, routing, delivery and trans-shipment (Barad \& Sapir, 2003; Das \& Nagendra, 1997); order quantity and delivery lead time flexibilities (Wang, 2008); sourcing flexibility (Narasimhan \& Das, 2000); launch flexibility and access flexibility (Sánchez and Pérez, 2005). Firm performance has presented another core theme in recent work, with results pointing to the importance of customer-supplier flexibility capabilities to improve competitiveness (Merschmann \& Thonemann, in press; Sánchez and Pérez, 2005). Duclos, Vokurka \& Lummus (2003) argue for the importance of organizational flexibility and information systems flexibility (in addition to operations system, market, logistics, and supply flexibility) so that the supply chains can function in a seamless succession of efficient processes; while More \& Babu (2009) claim that supply chain flexibility is a new strategic tool for management.

In thinking about the managerial implications of supply chain flexibility, it is useful to distinguish among 'flexible competencies' (internal flexibility issues from the supplier perspective) versus 'flexible capabilities' (customer perceptions on external flexibility issues) (Zhang, Vonderembse \& Lim, 2003). It is important in this regard to tease out the relevant factors for suppliers and customers using procedures like Delphi (Lummus, Vokurka \& Duclos, 2005), where the different attributes could be identified and unified metrics could be developed to enable communication across different perspectives (Gunasekaran, Patel \& 
McGaughey, 2004). This is a complicated issue with performance measurement being a multi-dimensional construct that needs to target operational parameters like efficiency in addition to the stakeholder exposure factors like control and accountability (Parmigiani, Klassen \& Russo, 2011).

Supply chain risks and disruptions can be caused by natural disasters, unexpected accidents, operational difficulties, terrorist incidents, and industrial or direct action. In any case, supply chains need to be flexible enough to recover from any disruptions at the earliest possible time. Moreover, it is possible to consider two different types of flexibility within the supply chain context; volume/capacity flexibility that allows to decrease or increase production according to the observed demand and delivery flexibility that allows to make changes to the deliveries, e.g. adapting new delivery amounts or delivery dates. In line with these ideas, Schutz and Tomasgard (2009) analyse volume, delivery, storage and operational decision flexibilities in a supply chain under uncertain demand and arrive at a trade-off between volume and delivery flexibility and operational decision and storage flexibility.

A recent survey on supply chain flexibility by More and Babu (2009) provides a comprehensive definition of flexibility within the context of supply chain, summarizes the methods used to model supply chain flexibility, and concludes with interesting future research avenues. Although there is no general agreement on how to define supply chain flexibility, the area has tremendous potential for researchers providing opportunities for modelling and application of flexibility to the supply chain, interrelationships and trade-offs between different types of flexibilities, industry-specific or business function-specific impact of flexibility, and/or potential barriers to the implementation of flexibility.

In this chapter, we aim to focus on the synergies between supply chain flexibility and forecasting, risk management, and decision making as the influential factors affecting performance and management of supply chains. In light of the scarcity of studies investigating supply chain flexibility and the pressing need for future work in this area, we aim to (1) provide a review of extant literature, (2) highlight emerging research directions, and (3) discuss managerial repercussions. In so doing, this chapter will emphasize three areas that collectively play a critical role in determining the effectiveness of flexible supply chains: forecasting, risk management, and decision making.

\section{Forecasting and supply chain flexibility}

Forecasts represent main inputs into planning and decision making processes in supply chains. Predictions of future demands, resource requirements and consumer needs present some areas where collaborative forecasting may play a significant role in contributing to flexible supply chain performance. In fact, the quality of decisions and the resulting outcomes may be argued to depend on the extent of information sharing and forecast communication in flexible supply chains.

Planning and decision making processes in supply chains heavily rely on forecasts. Accordingly, forecasting accuracy is a core factor that influences the performance of a supply chain (Zhao, Xie \& Leung, 2002). Bullwhip effect is a prime example of how predictive inaccuracy can easily intensify through the supply chain (Chang \& Lin, 2010), crippling the affected partners. Predictions of future demands, resource requirements and consumer needs present some areas where collaborative forecasting may play a significant role in contributing to flexible supply chain performance. 
While flexibility is argued to provide a way for eluding forecasting uncertainties (Bish, Muriel \& Biller, 2001), it may also be viewed as a means for benefitting from the informational advantages and forecasting expertise of supply chain partners (Småros, 2003). This may be especially critical given the strong influence of the organizational roles in guiding the individual and group forecasts (Önkal, Lawrence \& Sayım, 2011). Additionally, biases such as overconfidence and optimism are found to have significant effects on supply chain forecasts (Fildes et al, 2009), thus challenging predictive accuracy and synchronized information flow among the decision makers. All these factors make collaborative forecasting an indispensable tool for flexibility and responsive decision making in supply chains (Caridi, Cigolini \& de Marco, 2005; Derrouiche, Neubert \& Bouras, 2008), as well as for improving efficiency and competitiveness (Aviv, 2001; Helms, Ettkin \&Chapman, 2000).

Supply chain flexibility requires extensive information and forecast sharing, and thus is vulnerable to a variety of motivational factors that can potentially lead to significant distortions (e.g., Mishra, Raghunathan \& Yue, 2007). Various studies have clearly demonstrated the impact of such forecasting errors and distortions on supply chain performance (e.g., Zhao \& Xie, 2002; Zhu, Mukhopadhyay \&Yue, 2011). In this regard, the role of trust in collaborative forecasting presents an extremely promising research area. Supply chain relationships are acknowledged to rely on trust, with its role investigated mainly in the context of information sharing and information quality (e.g., Chen, Yen, Rajkumar \& Tomochko, 2010). This can easily be extended to studies that focus on how trust among partners could reduce individual and organizational biases (Oliva \& Watson, 2009), leading to forecast sharing and improved predictive accuracy for the whole supply chain.

In summary, collaborative forecasting and forecast sharing constitute vital areas for enhanced decision making in flexible supply chains. Further research in this domain is likely to face serious challenges emanating from behavioral factors and organizational dynamics, but the rewards to flexible supply chain management will surely be worth the effort.

\section{Risk management and supply chain flexibility}

Uncertainties in the operating environment of firms reduce the reliability in terms of delivering at the right time, at the right amount and quality. Uncertainty requires firms to quickly respond to changing environments. Operating in a flexible supply chain helps the firms to accomplish this rapid adaptation. On the other hand, increasing flexibility brings along additional risks for the firms to undertake. Alignment, adaptability and agility (flexibility) are fundamental elements for supply chain risk management. It is accepted that flexibility increases supply chain resilience; however, firms are reluctant to invest in flexibility when it is not clear how much flexibility is required. The higher the flexibility, the riskier is the chain. However, there are some methods and models which help to mitigate the level of risk associated with the level of flexibility. This section analyses the relationship between supply chain flexibility and supply network risk management.

An interesting study focusing on risk management in a supply chain that is subject to weather-related demand uncertainty is provided by Chen and Yano (2010). These researchers focus on a manufacturer-retailer dyad of a seasonal product with weather sensitive demand to examine weather-linked rebate for improving the expected profits. This is an extension of rebate contracts which have several advantages over other contract types 
such as no required verification of leftover inventory and/or markdown amounts, and no adverse effect on sales effort by the retailer. The paper reports interesting results on how the weather-linked rebate can take many different forms, and how this flexibility allows the supplier to design contracts that are Pareto improving and limit the reciprocal risks of offering and accepting the contract. The structural results can be extended to allow the two parties to limit their risk under the increased flexibility.

Table 1 lists a sample of relatively recent events that have affected the respective supply chains which would have turned out having very different outcomes if the supply chains had higher levels of flexibility and appropriate risk management practices.

\begin{tabular}{|c|c|c|}
\hline Event & Outcome & Reference \\
\hline $\begin{array}{l}\text { September 1999: Taiwan } \\
\text { earthquake }\end{array}$ & $\begin{array}{l}\text { Huge losses for many electronic firms that } \\
\text { use Taiwanese manufacturers as suppliers. }\end{array}$ & Sheffi, 2005 \\
\hline $\begin{array}{l}\text { March 2000: Fire at the } \\
\text { Philips microchip plant } \\
\text { in Albuquerque, NM. }\end{array}$ & $\begin{array}{l}\text { Nokia and Ericsson were affected. Nokia } \\
\text { resumed production in three days whereas } \\
\text { Ericsson shut down production with } \$ 400 \\
\text { million loss. }\end{array}$ & Latour, 2001 \\
\hline $\begin{array}{l}\text { April - June 2003: SARS } \\
\text { outbreak }\end{array}$ & $\begin{array}{l}\text { It is estimated that transportation industry } \\
\text { lost } 38 \text { billion RMB, wholesale and retail } \\
\text { trade industries lost } 12 \text { billion RMB and } \\
\text { manufacturing industry lost } 27 \text { billion RMB. }\end{array}$ & Ji and Zhu, 2008 \\
\hline $\begin{array}{l}\text { Summer 2004: Below- } \\
\text { average temperature } \\
\text { decreased the demand } \\
\text { for certain products }\end{array}$ & $\begin{array}{l}\text { Cadbury Schweppes' drinks business was hit } \\
\text { by soggy summer weather. } \\
\text { Coca-Cola and Unilever pointed the weather } \\
\text { for low sales of soft drink and ice cream } \\
\text { products. } \\
\text { Nestle reported decreased demand for ice- } \\
\text { cream and bottled water due to poor weather. }\end{array}$ & $\begin{array}{l}\text { Kleiderman, } \\
2004\end{array}$ \\
\hline $\begin{array}{l}\text { May 2008: earthquakes in } \\
\text { Sichuan, China }\end{array}$ & Severe damage to infrastructure network. & $\begin{array}{l}\text { Qiang and } \\
\text { Nagurney, } 2010\end{array}$ \\
\hline $\begin{array}{l}\text { March 2011: Japanese } \\
\text { earthquake }\end{array}$ & $\begin{array}{l}\text { Large negative impact on the economy of } \\
\text { Japan and major disruptions to global and } \\
\text { local supply chains. }\end{array}$ & $\begin{array}{l}\text { Nanto et al., } \\
2011\end{array}$ \\
\hline
\end{tabular}

Table 1. Key events and outcomes underlining the importance of risk management in supply chain

The list can easily be extended to include high profile events like natural disasters and terrorism attacks in different regions. All these occurrences have dramatic effects on the supply chains, whether these are humanitarian supply chains involving health aid or basic food supply chains. Further research into embedding emergency flexibilities in these chains via best case risk management practices will be extremely valuable for both the practitioners 
and the academics aiming to improve supply chain management performance under extremely demanding circumstances.

\section{Decision making and supply chain flexibility}

Existing literature defines supply chain flexibility as a reactive means to cope with uncertainty. Networked companies in a dynamic and complex environment require coordination of their multiple plants, suppliers, distribution centres, and retailers. There are numerous decision making models (linear, non-linear, and multi-objective) which aim for coordination of the supply network players and hence increase the overall flexibility of the chain.

Schutz and Tomasgard (2009) employ a stochastic programming model to balance supply and demand in a supply chain from the Norwegian meat industry. The authors find that a deterministic model of the supply chain produces as good results as does the stochastic model given a certain level of flexibility in the chain. The level of extra capacity required to obtain volume flexibility, number of products to achieve mix flexibility, or the level of procurement flexibility stand as important decisions in the supply chain to improve market responsiveness and resolve uncertainty-related problems. Das (2011) proposes a mixed integer programming model for supply chain to address demand and supply uncertainty along with market responsiveness. A scenario-based stochastic approach is utilized to model the demand behaviour where they test the supply chain flexibility based on a pool of suppliers. The proposed mixed integer programming model is tested to aid supply chain managers in setting supplier flexibility, capacity flexibility, product flexibility and customer service level flexibility.

On the other hand, Wadhwa and Saxena (2007) propose a decision knowledge sharing model to improve collaboration in flexible supply chains. The main benefit of the model is to facilitate sourcing and distribution decisions. Empirical results demonstrate that full decision-sharing in a flexible supply chain leads to decreased total costs.

Given the abundance of decision models that may be employed to adopt or increase supply chain flexibility, further work on comparative analysis of such models in different contexts with systematic variations in levels of uncertainty appears to be highly promising.

\section{Interconnectedness of forecasting, risk management and decision making}

The three areas of analysis are not mutually exclusive. There is a definite need for studies to focus on and explore the intersections of forecasting, risk management and decision making in the context of supply chain flexibility. We will discuss these interactions next.

\subsection{Decision making / risk management for supply chain flexibility}

Risk management and decision making are inherently intertwined. Their interactions gain a special significance for the plethora of managerial issues faced in efforts to introduce flexibility to different aspects of supply chains. Yu et al. (2009) focuses on a two-stage supply chain where the buying firm faces a non-stationary, price-sensitive demand of a critical component and where two suppliers (primary and secondary) are available. The authors suggest a mathematical model as a decision aid to choose the most profitable sourcing strategies in the presence of supply chain disruption risks. It should be noted that 
the demand model used in this study is fairly simple and the supplier's capacity is assumed to be infinite. One critical limitation of this study is that it considers only the buyer's profit instead of examining the sourcing decisions from both parties' point of view.

Giannikis and Louis (2001) develop a framework for designing a multi-agent decision support system to aid the management of disruptions and mitigation of risks in manufacturing supply chains. The agents responsible for communication, coordination, and disruption management are built to simulate the supply chain which is occasionally subject to abnormal events (e.g. an unusual fluctuation in the manufacturing process). Effective disruptions management is assumed under collaborative behavior of supply chain partners by learning from previous corrective actions for future decisions, suggesting risk mitigation at operational and tactical levels. The most important result of this analysis may be that risk management cannot be perceived as an individual process of each partner.

\subsection{Forecasting / risk management for supply chain flexibility}

Forecasts may be utilized as critical tools for risk management, and this gains a special significance for managing flexible supply chains. Introducing successful mechanisms for operational flexibilities throughout the supply chain requires effective integration of forecasts into risk management strategies. This is a vital and yet challenging process for supply chain management. Future work directed at exploring the role of forecasting - risk management interactions for the performance of supply chains and their flexibility concerns will prove especially useful in various contexts ranging from waste management to quality control.

\subsection{Forecasting / decision making for supply chain flexibility}

As far as the uncertainty in demand and supply processes is concerned, flexibility improves the performance of supply chains in terms of cost efficiencies and market response. The close interplay between forecasting and decision making plays a vital role in managing such uncertainties to expand the supply chain capabilities, resulting in enhanced system performance throughout. Management of flexible supply chains necessitates planning for alternative forecast scenarios and building efficient response strategies to tackle possibilities of disruptions/crises/alterations for a variety of factors. Strong coordination mechanisms among supply chain partners will be needed for information sharing, forecast adjustment/synchronization, and group decision making.

\section{Conclusion and directions for future research}

Integrating flexibility into supply chains requires building efficient response mechanisms for adapting to changes in a host of internal and external factors. In today's competitive and complex markets, supply chain management has to function along a dynamic interplay of forecasting, risk management and decision making challenges (Wadhwa, Saxena \& Chan, 2008). Developing effective supply chain strategies will need to involve a complicated mixture of incentive alignment, information sharing, decision synchronization and collaborative planning and forecasting (Cao \& Zhang, 2011; Derrouiche, Neubert \& Bouras, 2008; Simatupang \& Sridharan, 2005). Enhancing information visibility (Wang and Wei, 
2007), improving communication among supply chain partners, and developing effective collaborative forecasting and decision support tools will prove immensely valuable in attaining the desired strategic goals. The next decade of supply chain management research may be expected to start providing answers to the multi-disciplinary challenges associated with improving the global value and performance of flexible supply chains.

\section{References}

Aviv, Y. (2001), "The effect of collaborative forecasting on supply chain performance", Management Science, 47, 1326-1343.

Barad, M., and Nof, S., (1997), "CIM flexibility measures: A review and framework for analysis and applicability assessment", International Journal of Computer Integrated Manufacturing, 10, 296-308.

Barad, M., and Sapir, D., (2003), “Flexibility in logistic systems-modeling and performance evaluation", International Journal of Production Economics, 85, 155-170.

Bish, E.K., Muriel, A., and Biller, S. (2001), "Managing flexible capacity in a make-to-order environment", Management Science, 51, 167-180.

Cao, M., and Zhang, Q. (2010), "Supply chain collaboration: Impact on collaborative advantage and firm performance", Journal of Operations Management, 29, 163-180.

Caridi,M., Cigolini, R. and de Marco, D. (2005), "Improving supply-chain collaboration by linking intelligent agents to CPFR", International Journal of Production Research, 43, 4191-4218.

Chang, P.-C., and Lin, Y.-K. (2010), "New challenges and opportunities in flexible and robust supply chain forecasting systems ", International Journal of Production Economics, 128, 453-456.

Chen, J.V., Yen, D.C., Rajkumar, T.M., and Tomochko, N.A. (2010), “The antecedent factors on trust and commitment in supply chain relationships", Computer Standards $\mathcal{E}$ Interfaces, doi: 10.1016/j.csi.2010.05.003.

Chen, F.Y., Yano, C.A. (2010) Improving supply chain performance and managing risk under weather-related demand uncertainty, Management Science, 56(8), 13801397.

Das, K. (2011) Integrating effective flexibility measures into a strategic supply chain planning model, European Journal of Operational Research, 211(1), 170-183.

Das, S., and Nagendra, P. (1997), "Selection of routes in a flexible manufacturing facility", International Journal of Production Economics, 85, 171-181.

Derrouiche, R., Neubert, G., and Bouras, A. (2008), "Supply chain management: A framework to characterize the collaborative strategies", International Journal of Computer Integrated Manufacturing, 21, 426-439.

De Toni, A., and Tonchia, S. (1998), "Manufacturing flexibility: A literature review", International Journal of Production Research, 36, 1587-1617.

Derrouiche, R., Neubert, G., and Bouras, A. (2008), “Supply chain management: A framework to characterize the collaborative strategies", International Journal of Computer Integrated Manufacturing, 21, 426-439. 
Duclos, L.K., Vokurka, R.J., and Lummus, R.R. (2003), “A conceptual model of supply chain flexibility", Industrial Management \& Data Systems, 103, 446-456.

Fildes, R., Goodwin, P., Lawrence, M. and Nikolopoulos, K. (2009). "Effective forecasting and judgmental adjustments: An empirical evaluation and strategies for improvement in supply-chain planning". International Journal of Forecasting, 25, 3-23.

Giannakis, M., Louis, M. (2011) A multi-agent based framework for supply chain risk management, Journal of Purchasing and Supply Management, 17(1), 23-31.

Gunasekaran, A., Patel, C., and McGaughey, R.E. (2004), “A framework for supply chain performance measurement", International Journal of Production Economics, 2004, 333347.

Gupta, Y.P., and Goyal, S. (1989), “Flexibility of manufacturing systems: Concepts and measurements", European Journal of Operational Research, 43, 119-135.

Helms, M.M., Ettkin, L.P., and Chapman, S. (2000), “Supply chain forecasting: Collaborative forecasting supports supply chain management", Business Process Management, 6, 392-407.

Ji, G. and Zhu, C. (2008) Study on Supply Chain Disruption Risk Management Strategies and Model, International Conference on Service Systems and Service Management, June 30 2008-July 2 2008, Melbourne, VIC.

Kaighobadi, M., and Venkatesh, K. (1994), "Flexible manufacturing systems: An overview", International Journal of Operations \& Production Management, 14, 4, 26-49.

Kleiderman, A. (2004). Soggy summer spells boardroom gloom. BBC News (September 24), http://news.bbc.co.uk/1/hi/business/3686742.stm date accessed: March 10, 2011.

Koste, L.L., and Malhotra, M.K. (1999), "A theoretical framework for analyzing the dimensions of manufacturing flexibility", Journal of Operations Management, 18, 7593.

Latour, A. (2001) Trial by fire: a blaze in Albuquerque sets off major crisis for cell-phone giants, The Wall Street Journal; Eastern Edition, January 29.

Lummus, R.R., Vokurka, R.J., and Duclos, L.K. (2005), “Delphi study on supply chain flexibility", International Journal of Production Research, 43, 2687-2708.

Mascarenhas, B. (1981), "Planning for flexibility", Long Range Planning, 14, 74-78.

Merschmann, U., and Thonemann, U.W. (in press), "Supply chain flexibility, uncertainty and firm performance: An empirical analysis of German manufacturing firms", International Journal of Production Economics, doi:10.1016/j.ijpe.2010.10.013.

Mishra, B.K., Raghunathan, S., and Yue, X. (2007), "Information sharing in supply chains: Incentives for information distortion", IIE Transactions, 39, 863-877.

More, D., Subash Babu, A. (2009) Supply chain flexibility: a state-of-the-art survey, International Journal of Services and Operations Management, 5(1), 29-65.

Nanto, D.K., Cooper, W.H., Donnelly, J.M., and Johnson, R. (2011) Japan's 2011 Earthquake and Tsunami: Economic Effects and Implications for the United States, CRS Report for Congress, https://www.fas.org/sgp/crs/row/R41702.pdf date accessed: May 10, 2011.

Narasimhan, R., and Das, A. (2000), “An empirical examination of sourcing's role in developing manufacturing flexibilities", International Journal of Production Research, $38,875-893$. 
Oliva, R., and Watson, N. (2009), “Managing functional biases in organizational forecasts: A case study of consensus forecasting in supply chain planning", Production and Operations Management, 18, 138-151.

Önkal, D., Lawrence, M,. and Sayım, K. Z. (2011), “ Influence of differentiated roles on group forecasting accuracy", International Journal of Forecasting, 27, 50-68.

Parker, R.P., and Wirth, A. (1999), "Manufacturing flexibility: Measures and relationships", European Journal of Operational Research, 118, 429-449.

Parmigiani, A., Klassen, R.D., and Russo, M.V. (2011), “Efficiency meets accountability: Performance implications of supply chain configuration, control, and capabilities", Journal of Operations Management, 29, 212-223.

Qiang, Q. and Nagurney, A., (2010) A Bi-Criteria Measure to Assess Supply Chain Network Performance for Critical Needs Under Capacity and Demand Disruptions (January 15, 2010). Transportation Research, 2010. Available at SSRN: http:/ / ssrn.com/abstract $=1731943$

Sánchez, A.M., and Pérez, M.P. (2005), "Supply chain flexibility and firm performance", International Journal of Operations \& Production Management, 25, 681-700.

Schutz, P., Tomasgard, A., (2009) The impact of flexibility on operational supply chain planning. International Journal of Production Economics, doi:10.1016/j.ijpe.2009.11.004

Sethi, A.K., and Sethi, S.P. (1990), "Flexibility in manufacturing: A survey", International Journal of Flexible Manufacturing Systems, 2, 289-328.

Sheffi Y. (2005) The resilient enterprise. Cambridge, MA: MIT Press.

Simatupang, T.M., and Sridharan, R. (2005), "An integrative framework for supply chain collaboration", International Journal of Logistics Management, 16, 257-274.

Småros, J. (2003), "Collaborative forecasting: A selection of practical approaches", International Journal of Logistics Research and Applications, 6, 245-258.

Vickery, S., Calantone, R., and Drőge, C. (1999), "Supply chain flexibility: An empirical study", The Journal of Supply Chain Management, Summer, 16-24.

Wadhwa, S., Saxena, A. (2007) Decision knowledge sharing: flexible supply chains in KM context, Production Planning \& Control, 18(5), 436-452.

Wang, E.T.G, and Wei, H.-L. (2007), "Interorganizational governance value creation: Coordinating for information visibility and flexibility in supply chains", Decision Sciences, 38, 647-674.

Wang, Y.-C. (2008), "Evaluating flexibility on order quantity and delivery lead time for a supply chain system", International Journal of Systems Science, 39, 1193-1202.

Yu, H., Zeng, A.Z., Zhao, L. (2009). Single or dual sourcing: decision-making in the presence of supply chain disruption risks. Omega, 37, 788-800.

Zhang, Q., Vonderembse, M.A., and Lim, J.S. (2003), "Manufacturing flexibility: Defining and analyzing relationships among competence, capability and customer satisfaction", Journal of Operations Management, 21, 173-191.

Zhao, X., and Xie, J. (2002), "Forecasting errors and the value of information sharing in a supply chain", International Journal of Production Research, 40, 311-335.

Zhao, X., Xie, J., and Leung, J. (2002), "The impact of forecasting model selection on the value of information sharing in a supply chain", European Journal of Operational Research, 142, 321-344. 
Zhu, X., Mukhopadhyay, S.K. and Yue, X. (2011), “Role of forecast errors on supply chain profitability under various information sharing scenarios", International Journal of Production Economics, 129, 284-291. 


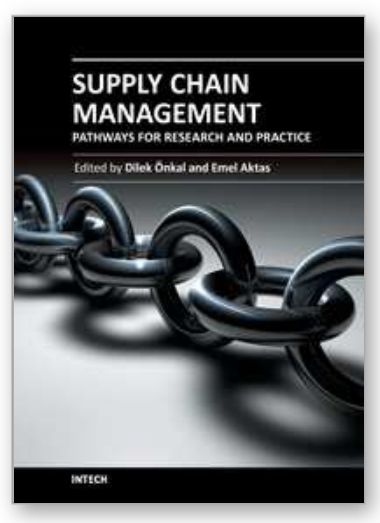

\author{
Supply Chain Management - Pathways for Research and Practice \\ Edited by Prof. Dilek Onkal
}

ISBN 978-953-307-294-4

Hard cover, 234 pages

Publisher InTech

Published online 01, August, 2011

Published in print edition August, 2011

Challenges faced by supply chains appear to be growing exponentially under the demands of increasingly complex business environments confronting the decision makers. The world we live in now operates under interconnected economies that put extra pressure on supply chains to fulfil ever-demanding customer preferences. Relative attractiveness of manufacturing as well as consumption locations changes very rapidly, which in consequence alters the economies of large scale production. Coupled with the recent economic swings, supply chains in every country are obliged to survive with substantially squeezed margins. In this book, we tried to compile a selection of papers focusing on a wide range of problems in the supply chain domain. Each chapter offers important insights into understanding these problems as well as approaches to attaining effective solutions.

\title{
How to reference
}

In order to correctly reference this scholarly work, feel free to copy and paste the following:

Dilek Onkal and Emel Aktas (2011). Supply Chain Flexibility: Managerial Implications, Supply Chain Management - Pathways for Research and Practice, Prof. Dilek Onkal (Ed.), ISBN: 978-953-307-294-4, InTech, Available from: http://www.intechopen.com/books/supply-chain-management-pathways-for-researchand-practice/supply-chain-flexibility-managerial-implications

\section{INTECH}

open science | open minds

\author{
InTech Europe \\ University Campus STeP Ri \\ Slavka Krautzeka 83/A \\ 51000 Rijeka, Croatia \\ Phone: +385 (51) 770447 \\ Fax: +385 (51) 686166 \\ www.intechopen.com
}

\author{
InTech China \\ Unit 405, Office Block, Hotel Equatorial Shanghai \\ No.65, Yan An Road (West), Shanghai, 200040, China \\ 中国上海市延安西路65号上海国际贵都大饭店办公楼405单元 \\ Phone: +86-21-62489820 \\ Fax: $+86-21-62489821$
}


(C) 2011 The Author(s). Licensee IntechOpen. This chapter is distributed under the terms of the Creative Commons Attribution-NonCommercialShareAlike-3.0 License, which permits use, distribution and reproduction for non-commercial purposes, provided the original is properly cited and derivative works building on this content are distributed under the same license. 